Dr. Beale, as is well known, still holds to the opinion that the nerve-force is electricity, and that the nerves have not only the power of conducting electricity but of evolving it as a vital act on stimulation from the little masses of protoplasm, bioplasm, or living matter with which the nerve-cords are studded. Although there are many ohjections to this theory, still the badly-conducting power of the nerves for electricity does not appear an insuperable one when we think of the nerve-force merely as a stimulus, for the quantity of a stimulus necessary to rouse up vital action bears an infinitesimally small proportion to the result. But when the same force is assumed to be the efficient cause of muscular contraction, the question assumes a very different aspect. In Dr. Beale's theory the muscular fibre proper is held not to contain protoplasm, and to be incapable of living action or of evolving force, the contraction being produced by inductive electric action on the sarcous particles, which causes them to change their position and thus approximate the ends of the muscular fibre. The source of the electricity is said to be the protoplasm masses contained in the muscles, in continuous contact with the motor nerves, and it is conveyed to the muscular fibres by loops of fine nerve-fibres crossing them in various directions. In this theory, even supposing insulation to be complete, it is obvious that the conducting power of the nerve-fibre becomes of supreme importance, because not the stimulus only, but the whole force of muscular motion, must be conveyed by it. Now, the nerve-cords do conduct electricity certainly, but so many million times worse than metallic wires, that the loss of energy by transformation into heat must be enormous. Such a loss is inconsistent with the economy of nature and with the actual facts; therefore, unless the nerve-force is a specific force different from surface-electricity, galvanism, and magnetism, though analogous to them, and probably easily convertible into electricity, Dr. Beale's theory cannot be upheld. I have not yet seen any reply by Dr. Beale to this objection.

Liverpool JOHN DRXSDALE

\section{Kirkes' Physiology}

IN a letter headed "Kirkes' Physiology," in Narune of last week, signed "W. Percy Ashe," your correspondent wonld not appear to be practically acquainted with the semi-lunar valves at the base of the great vessels emerging from the beart, for his arguments, although perfectly correct in themselves, and based on well-known physical laws, do not, I submit, apply in the instance he quotes, for the simple reason that the conditions necessary for their application do not exist.

Let us consider briefiy the shape of the sinuses of Valsalva during the diastole of the ventricles of the heart. For our purpose we shall be sufficiently correct in describing them as three inverted, cmpty, and slightly truncated pyramids ; one surface, the outer one, of each; is formed by the arterial coat, whilst the otl er two surraces, constituting the semi-lunar valve, are in apposition with the corresponding surfaces of the other two valves. Now, the pressure over the whole surface of the sinus may be divided into four pressures, one sustained by each of the three sides, and one by the bottom.

The three sides sustain an equal pressure, but the two inner ones constituting the valve are by far the weakest, and the pressure on each of these is really supported by an equal pressure on the corresponding surfaces of the other two valves, and consequently may be considered as nil; whilst the pressure on the third side is resisted by its own strength, and it is formed, as I have said, by the wall of the artery, which is particularly strong at this point.

The remaining pressure is sustained by the bottom or truncated apex of the pyramidal pouch. This pressure is greater in proportion to its extent of surface than the other pressuresthe column of fluid being higher-and this surface directly rests on and is partially embedded in the structure of the ventricle, which must thus undoubtedly support it.

Therefore the idea that "the reflux is most efficiently sustained by the muscular substance of the ventricle," which is the main part of Mr. Savory's theory, is most directly confirmed by the actual construction of the valves, and which your correspondent may see for himself by making a vertical section through the aortic valves in a sheep's heart.

As at the time of the greatest pressure on the valves the ventricles are dilating, it follows that they cannot reduce the area of the valves at that time, as your correspondent in his last remarks would seem to imagine, nor in fact can they ever do so. 4, Granville Place, Blackheath
E. PRIDEAux
The Rhinoceros in New Guinea

Lieut. Sidney SMith, late of H.M.S. Basilisk, reports that while engaged in surveying on the north coast of Papua, between Huon Bay and Cape Basilisk, being on shore with a party cutting firewood, he observed in the forest the "droppings" (excrement) of a rhinoceros in more than one place, the bushes in the neighbourhood being also broken and trampled as if by a large animal. The presence of so large an animal belonging to the Asiatic fauna in Papua is an important fact.

Skins of a very fine species of Bird of Paradise, having plumes of a brilliant red in place of the yellow plumes of the common species $(P$. apod $a)$, were obtained from the natives further to the eastward.

Chester, Jan. 2r

[We should be inclined to doubt very seriously the occurrence of any rhinoceros in New Guinea. At any rate, the important fact, as our correspondent terms it, cannot be considered as established.

The red-plumed Paradise Bird of the south of New Guinea has been named by Mr. Sclater, Paradisea raggiana (P. Z. S., I 873 , p. 559), from skins sent home by Mr. D'Albertis.-Ev.]

\section{Thomson's "Malacca"}

In your review (NATURE, vol. xi. p. 207) of Mr. J. Thom. son's very interesting work on the "Straits of Malacca, IndoChina, and China," you have justly acknowledged that the author " nakes no pretension to have travelled in the interests of science, but only to be a photographer and an observer of the ways of men;" and as his excellent book will no doubt have a wide circulation, it may perhaps not be an unthankful office to correct two statements with reference to the natural history of Penang, which I had some opportunity of studying during a sojourn there of some eighteen months.

Our author, describing the noise made by the insects on Penang Hill, says: "One beetle in particular, known to the natives as the 'trumpeter' busies himself all day long in producing a booming noise with his wings." Had Mr. Thomson succeeded in observing one of these insects whilst "booming," which he states he was unable to do, I think he would have found the musician to have been no beetle at all, but one of the Cicadidre, and the sound not produced by the wings, but, as is generally known, internally, by the vibration of a membrane set into action by a special muscle. These insects are abundant at Penang, one species, Dundubia imperatoria, being particularly large, and which, with several other species, were taken by myself when there. It is nothing unusual for these insects to be wrongly described by natives, as we are told by Mr. Gervase F. Mathew, R.N. (in the Entomologist's Monthly Magazine), that in Tobago Cicada gigas makes a noise like the whistle of a locomotive; and he was tuld by the natives that the sound was that of the "tree-locust." At Surinam it is said Cicada tibicen is called the "harper," on account of its giving forth a sound like that of a harp.

Mr. Thomson also tells us (p. 35), when describing planter life in Province Wellesley, that the planters, when driving home at night from one estate to another, have the possibility of an encounter with an orang-outan, a rhinoceros, or a tiger. The orang, however, is not found there at all, and I know of no instance of an attack by a rhinoceros. In fact, that animal is so scarce that during my whole stay there the only report of one which I heard was that the animal's dung had been seen in the jungle. Tigers are still anything but scarce, but during my many nightly rides whilst living on the sugar plantations $I$ am happy to say I never heard or saw one, nor was our roll-call ever diminished by that animal. The tiger there is a midnight prowler, but confines himself more to pigs, goats, and dogs. The wild animals are gradually being beaten back by the cultivation of the land, and the same may be said of even the insects. No doubt they abound in the centre of the peninsula, and there also, no doubt, may be found the Negrito stock, of which our author has given us a good photograph as found at Johore.

The illustrations of this very interesting book are excellent, and photography seems to be doing for anthropology what spectrum analysis is still achieving for astronomy.

Streatham Cottage, West Dulwich

W. L. Distant

\section{Bees and Flowers}

MY children noticed with much interest, last autumn, the curious manner that the bees attacked the flowers of the Antir. 